\title{
Workloads and strain process in Community Health Agents*
}

\author{
Cargas de trabalho e processo de desgaste em Agentes Comunitários de Saúde \\ Cargas de trabajo y proceso de desgaste en Agentes Comunitarios de Salud
}

\author{
Mirian Cristina dos Santos Almeida ${ }^{1}$, Patricia Campos Pavan Baptista ${ }^{2}$, Arlete Silva $^{3}$
}

\section{How to cite this article:}

Almeida MCS, Baptista PCP, Silva A. Workloads and strain process in Community Health Agents. Rev Esc Enferm USP. 2016;50(1):93-100. DOI: http://dx.doi. org/10.1590/S0080-623420160000100013

\footnotetext{
* Extracted from the dissertation "Acidentes de trabalho ocorridos com Agentes Comunitários de Saúde no município de Caraguatatuba-SP”, Universidade Guarulhos, 2013.

${ }^{1}$ Universidade de São Paulo, Escola de Enfermagem, Programa de Pós-Graduação em Gerenciamento em Enfermagem, São Paulo, SP, Brazil.

${ }^{2}$ Universidade de São Paulo, Escola de Enfermagem, Departamento de Orientação Profissional, São Paulo, SP, Brazil.

${ }^{3}$ Universidade de São Paulo, Escola de Enfermagem, São Paulo, SP, Brazil.
}

\section{ABSTRACT}

Objective: To identify the workloads present in the work activities of community health agents (CHAs) and the resulting strain processes. Method: A descriptive, exploratory, cross-sectional and quantitative study conducted with 137 CHAs. Data were collected through a questionnaire and interview guided by the health surveillance software called SIMOSTE (Health Monitoring System of Nursing Workers), following the ethical codes of the current law. Results: In total, were identified 140 workloads involved in 122 strain processes, represented by the occurrence of health problems of the CHAs. The mechanical (55.00\%) and biological (16.43\%) loads stood out. The most common strain processes were the external causes of morbidity and mortality (62.31\%) and diseases of the musculoskeletal system and connective tissue (10.66\%). Conclusion: From the identified overloads, it became evident that all workloads are present in the work process of CHAs, highlighting the mechanical load, represented mainly by external causes of morbidity and mortality that are related to occupational accidents.

\section{DESCRIPTORS}

Community Health Agents; Workload; Occupational Risks; Occupational Health. 


\section{INTRODUCTION}

In Brazil, the Community Health Agent (CHA) is a member of the Family Health Strategy (FHS) that is considered one of the main gateways in the health system and a priority in the consolidation and expansion of basic health care. Each FSH team includes at least a doctor, a nurse, a nursing assistant or technician, and up to 12 Community Health Agents. The team is responsible for monitoring all the families within a territory called Area. The Area is divided into Microareas, where the CHA is responsible for up to 750 people $^{(1)}$.

The number of FHS teams in Brazil has grown considerably, and consequently, the number of CHAs rose from 59,066 in July 1998 to 269,604 in November 2014, serving more than 128.5 million Brazilians ${ }^{(2)}$.

In the FHS, the CHAs act as links between the population and other team members. Their specific functions include the registration and monitoring through monthly household visits to all families of their microarea; guidance on the use of health services; the development of activities of health promotion, prevention of diseases and disorders, and bealth surveillance individually or through health education groups. CHAs must also carry out the follow up of people with health problems and those registered in programs for income transfer and coping with vulnerabilities implemented by the state. However, the work process of CHAs requires collective cooperation of the FHS team members, aiming at improving the health conditions in the community where they operate through actions of prevention, promotion and restoration of health ${ }^{(1)}$.

Studies show the work suffering of CHAs, who travel long distances under adverse weather conditions, visit families in vulnerable conditions, witness violence situations, have contact with hazardous areas, unhealthy places, drug dealing spots and homes with vicious dogs. The impotence and lack of support from other team members and management in relation to solving the health problems of families appear as stressors. As they are community members and reside in their area of operation, the CHAs interact with the families of their microarea of coverage the whole time, and are often charged for actions that escape their governance ${ }^{(3-4)}$.

Thus, CHAs are exposed to numerous inadequate conditions at work that can generate work-related accidents or diseases, highlighting the impact of the work process on the health. Starting from the social determination of the healthdisease process, the workloads are defined as the work process elements that interact with each other and with the body of workers, producing adaptation processes that result in strain, characterized by loss of body and psychic capacities ${ }^{(5)}$.

The workloads are classified into physical, chemical, biological, mechanical, physiological and psychological. The first four have external materiality and are independent of the worker's body; the physiological and psychological loads acquire materiality in the human body by producing changes in its internal processes, are not visible and can be identified by the strain produced in the worker's body. The physical loads can be exemplified by noise and heat; the chemical loads by dust, smoke, fibers, vapors, and liquids; and the biological by microorganisms. The mechanical loads are related to the instantaneous break of continuity of the body, as lesions due to injuries and fractures, among others; the physiological loads can be exemplified by heavy physical exertion, uncomfortable position, and change of shifts; and the psychological loads by situations that cause mental overload (prolonged stress, high hazard awareness, supervision with pressure) and mental underload (impossibility of using psychological abilities, repetitive activities, separation between planning and execution $)^{(5)}$.

The interest for this study resulted from the concern with the health of CHAs considering the insertion of these workers in the work process in health and the significant number of these professionals in the Brazilian scene. With the view that the production process determines the forms of illness, it is important to have a look that transcends the cause-effect relationship for the origin of the diseases presented by these workers. In literature, there is also a scarcity of studies focused on the analysis of the strain processes resulting from the work of CHAs based on social determination. Thus, this study aimed to identify the workloads present in the labor activity of CHAs and the resulting strain processes.

\section{METHOD}

This is a descriptive, exploratory, cross-sectional, field study of quantitative approach. It was carried out in $11 \mathrm{Ba}-$ sic Health Units that are home to 20 FHS teams and two teams of the Community Health Agents Strategy in the city of Caraguatatuba, state of São Paulo, Brazil.

The study included $137 \mathrm{CHAs}$ of the 166 that comprise the total team of CHAs of the Family Health Strategy/ Community Health Agents Strategy. Of the 29 CHAs not involved in the study, four were on sick leave, 16 on holidays, two refused to participate and seven were in the admission process. The inclusion criterion was to be performing their work duties on the day of data collection.

Data collection was conducted by one of the researchers after authorization of the Municipal Health Department of Caraguatatuba, and approval of the Research Ethics Committee (REC) of the Universidade Guarulhos (Number 723/11), following the ethical principles of Resolution 196/96, current 466/2012. After prior contact and scheduling of participation in a team meeting, the researcher invited the CHAs to participate in the study. Those who agreed signed the Informed Consent in two copies and answered a questionnaire containing sociodemographic data and workrelated data. Then, a semi-structured interview was conducted with data from health problems related to work: presence of any disease related to the type of work performed and if the person had suffered any work-related accident as a CHA with detailed description of the accident. The application of the questionnaire and the interview were conducted individually in a private room, ensuring privacy of the study subjects. The health surveillance software called SIMOSTE, the Health Monitoring System of Nursing Workers, was used as guidance for the interview. This software was developed to collect the health problems related to the determining loads of the processes of strain/disease ${ }^{(6)}$. 
The collected data were entered into a Microsoft Office Excel 2007 spreadsheet, analyzed using simple descriptive statistics, and presented in tables with absolute and relative frequencies, mean and standard deviation. The strain processes were classified according to the International Statistical Classification of Diseases and Related Health Problems (ICD-10), and the workloads were identified from the model adopted by Felli ${ }^{(7)}$, who applied the theoretical framework of Laurell and Noriega ${ }^{(5)}$ in nursing workers. This framework is guided by the social determination of the health-disease process, based on the work process, processes of exhaustion, profile of workers' disease and workloads.

\section{RESULTS}

Regarding the sociodemographic characteristics, most CHAs $(129 ; 94.16 \%)$ were female with a mean age of 34.79 years $(\mathrm{SD} \pm 9.96)$, living in a stable union $(83 ; 60.58 \%)$ and with one or two children $(82 ; 59.85 \%)$. Ninety-seven CHAs (70.80\%) contribute partially with the family income, which has the value of less than $\mathrm{R} \$ 2,000.00$ (90; 65.69\%). The average time of work as a CHA was 3.17 years $(\mathrm{SD} \pm 2.88$ years $)$, and more than half $(84 ; 61.31 \%)$ had been working as a CHA for less than three years. The most used type of transportation to go from home to the basic health unit and to perform their work in the microarea was the bicycle (83.21\% and 75.91\%, respectively) and walking (10.22\% and $11.68 \%$, respectively). Other mentioned types of transportation were the motorcycle, car or bus.

The workloads were quantified from the strain processes, identifying 140 workloads involved in 122 harmful incidents to the health of CHAs, evidenced by diseases and work accidents reported by the CHAs. Note that the occurrence of a health problem may be associated with more than a workload (Chart 1 ).

Of the 140 identified workloads, the mechanical loads were the most common $(77 ; 55.00 \%)$, followed by biological $(23 ; 16.43 \%)$, physiological $(20 ; 14.29 \%)$, psychological (15; 10.71\%), physical (4; $2.86 \%)$, and chemical $(1 ; 0.71 \%)$.

In this sense, the CHAs are exposed to all kinds of loads in the interaction with the elements of their working process, reflecting on their health, expressed by the strain processes.

Chart 1 - Strain processes mentioned by the CHAs according to exposure to workloads - Caraguatatuba, SP, Brazil, 2012.

\begin{tabular}{|c|c|}
\hline Workloads & Strain processes \\
\hline $\begin{array}{l}\text { Biological } \\
\text { Contact with patients with infectious } \\
\text { and parasitic diseases, contact with } \\
\text { animals in their work microarea, } \\
\text { contaminated material handling. }\end{array}$ & $\begin{array}{l}\text { - Bitten or struck by dog (13) } \\
\text { - Conjunctivitis (3) } \\
\text { - Acute infections of the upper airways (common cold, sinusitis, tonsillitis) (3) } \\
\text { - Exposure to other inanimate mechanical forces (cut with tin and broken } \\
\text { toilet during dengue preventive inspection in the community) (2) } \\
\text { - Perforation with hypodermic needle (contaminated) (1) } \\
\text { - Fall from one level to another (in the septic tank of the patients' houses backyard) (1) }\end{array}$ \\
\hline $\begin{array}{l}\text { Physical } \\
\text { Exposure to solar radiation. }\end{array}$ & $\begin{array}{l}\text { - Skin disorders related to ionizing radiation (3) } \\
\text { - Subnormal o impaired vision by sun exposure (1) }\end{array}$ \\
\hline $\begin{array}{l}\text { Chemical } \\
\text { Exposure to dust from unpaved public roads. }\end{array}$ & - Allergic rhinitis (1) \\
\hline $\begin{array}{l}\text { Mechanical } \\
\text { Instantaneous break of continuity of the } \\
\text { body via animal bite, traffic accidents, } \\
\text { falls, perforating agents, among others. }\end{array}$ & $\begin{array}{l}\text { - Bitten or struck by dog (13) } \\
\text { - Open wound of toe(s) with damage to nail (1) } \\
\text { - Injured pedestrian in collision with car (1) } \\
\text { - Pedal cyclist (CHA) injured in transport accidents (43) } \\
\text { - Motorcycle rider (CHA) injured in transport accidents (2) } \\
\text { - Foreign object penetration through the skin (thorn) (1) } \\
\text { - Perforation with hypodermic needle (1) } \\
\text { - Fall (on stairs or steps, from one level to another, at the same } \\
\text { level from slipping, tripping or stumbling) (12) } \\
\text { - Exposure to other inanimate mechanical forces (cut with } \\
\text { tin and broken toilet; injury with bicycle rim) (3) }\end{array}$ \\
\hline $\begin{array}{l}\text { Physiological } \\
\text { Walking long distances on foot or by bicycle, } \\
\text { carrying weight (work materials); inappropriate } \\
\text { and repetitive positions (taking notes frequently, } \\
\text { stopping the bike repeated times, and } \\
\text { adoption of other uncomfortable positions); } \\
\text { intense work pace to meet productivity } \\
\text { demands; deficient fluid intake; inadequate } \\
\text { diet (fast food, high in fat and low in fiber). }\end{array}$ & $\begin{array}{l}\text { - Synovitis and tenosynovitis (5) } \\
\text { - Back pain; limb pain (2) } \\
\text { - Shoulder injury (1) } \\
\text { - Calcaneal spur (1) } \\
\text { - Internal disorder of the knee (3) } \\
\text { - Coxarthrosis [arthrosis of the hip] (1) } \\
\text { - Varicose veins (2) } \\
\text { - Headache (1) } \\
\text { - Umbilical hernia (1) } \\
\text { - Cholelithiasis (1) } \\
\text { - Renal calculi (1) } \\
\text { - Cystitis (1) }\end{array}$ \\
\hline $\begin{array}{l}\text { Psychic } \\
\text { Accelerated pace of work, constant attention } \\
\text { in providing information and guidance and } \\
\text { while moving from a residence to another, } \\
\text { psychological aggression, predominantly female } \\
\text { work, constant contact with the diversity of } \\
\text { biopsychosocial problems of the community. }\end{array}$ & $\begin{array}{l}\text { - Reactions to severe 'stress' and adjustment disorders (4) } \\
\text { - Other anxiety disorders (1) } \\
\text { - Sleep disorders (2) } \\
\text { - Headache (1) } \\
\text { - Hypertensive diseases (5) } \\
\text { - Ulcer of the lower limbs ('autoimmune') (1) } \\
\text { - Hypothyroidism (1) }\end{array}$ \\
\hline
\end{tabular}


The strain processes mentioned by the CHAs were classified according to the ICD-10 and are represented in table 1 .

Table 1 - Distribution of the strain processes reported by the CHAs, classified according to the ICD-10 - Caraguatatuba, SP, Brazil, 2012.

Disease Groups - ICD-10
Endocrine, nutritional and metabolic diseases

E00-E07 Disorders of thyroid gland (hypothyroidism)

\begin{tabular}{|c|c|}
\hline $\mathbf{N}$ & $\%$ \\
\hline 01 & 0.82 \\
\hline 01 & 0.82 \\
\hline 05 & 4.10 \\
\hline 05 & 4.10 \\
\hline 02 & 1.64 \\
\hline 02 & 1.64 \\
\hline 04 & 3.28 \\
\hline 03 & 2.46 \\
\hline 01 & 0.82 \\
\hline 07 & 5.74 \\
\hline 05 & 4.10 \\
\hline 02 & 1.64 \\
\hline 04 & 3.28 \\
\hline 03 & 2.46 \\
\hline 01 & 0.82 \\
\hline 02 & 1.64 \\
\hline 01 & 0.82 \\
\hline 01 & 0.82 \\
\hline 04 & 3.28 \\
\hline 03 & 2.46 \\
\hline 01 & 0.82 \\
\hline 13 & 10.66 \\
\hline 01 & 0.82 \\
\hline 03 & 2.46 \\
\hline 01 & 0.82 \\
\hline 08 & 6.56 \\
\hline 02 & 1.64 \\
\hline 01 & 0.82 \\
\hline 01 & 0.82 \\
\hline 01 & 0.82 \\
\hline 01 & 0.82 \\
\hline 01 & 0.82 \\
\hline 01 & 0.82 \\
\hline 76 & 62.31 \\
\hline 01 & 0.82 \\
\hline 43 & 35.25 \\
\hline 02 & 1.64 \\
\hline 12 & 9.84 \\
\hline 05 & 4.10 \\
\hline 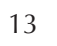 & 10.66 \\
\hline & 100.00 \\
\hline
\end{tabular}

Mental and behavioral disorders

F40-F48 Neurotic, stress-related and somatoform disorders

Diseases of the nervous system

G40-G47 Episodic and paroxysmal disorders (G47 Sleep disorders)

Diseases of the eye and adnexa

H10-H13 Disorders of conjunctiva (H10 Conjunctivitis)

H53-H54 Visual disturbances and blindness (H54.2 Moderate visual impairment, binocular)

Diseases of the circulatory system

I10 - I15 Hypertensive diseases

I80-189 Diseases of veins, lymphatic vessels and lymph nodes, not elsewhere classified (I83 Varicose veins of lower extremities)

Diseases of the respiratory system

J00-J06 Acute upper respiratory infections (common cold, sinusitis, tonsillitis)

J30-J39 Other diseases of upper respiratory tract (J30 Vasomotor and allergic rhinitis)

Diseases of the digestive system

K40-K46 Hernia (K42 Umbilical hernia)

K80 - K87 Disorders of gallbladder, biliary tract and pancreas (K80 Cholelithiasis)

Diseases of the skin and subcutaneous tissue

L55-L59 Radiation-related disorders of the skin and subcutaneous tissue

L80-199 Other disorders of the skin and subcutaneous tissue (Ulcer of lower limb - 'autoimmune')

Diseases of the musculoskeletal system and connective tissue

M15-M19 Arthrosis (M16 Coxarthrosis [arthrosis of the hip])

M20-M25 Other joint disorders (M23 Internal disorders of the knees)

M50-M54 Other dorsopathies (M54 Back pain)

M60-M79 Soft tissue disorders (M65 Synovitis and tenosynovitis; M75 Shoulder injury; M77.3 Calcaneal spur; M79.6 Pain in limb)

Diseases of the genitourinary system

N20-N23 Urolithiasis

N30-N39 Other diseases of urinary system (N30 Cystitis)

Symptom, signs and abnormal clinical and laboratory findings, not elsewhere classified

R50-R69 General symptom and signs (R51 Headache)

Injury, poisoning and certain other consequences of external causes

S90-S99 Injuries to the ankle and foot (S91.2 Open wound of toe(s) with damage to nail)

External causes of morbidity and mortality

V00-V09 Pedestrian injured in transport accident (V03 collision with car)

V10-V19 Pedal cyclist injured in transport accident

V20-V29 Motorcycle rider injured in transport accident (V28 without collision)

W00-W19 Falls

W20-W49 Exposure to inanimate mechanical forces

W50-W64 Exposure to animated mechanical forces (W54 Bitten or struck by dog)

Total

posure to animated mechanical forces (10.66\%), and falls

The CHAs have reported 122 health problems related to work. The most common were external causes of morbidity and mortality with $62.31 \%$, highlighting the pedal cyclist (CHA) injured in transport accident (35.25\%), ex-

(9.84\%), followed by diseases of the musculoskeletal system and connective tissue (10.66\%).

Of the strain processes mentioned by CHAs, it was 
found that $52.46 \%$ (64) were due to typical work accidents, $36.89 \%$ (45) of work-related diseases, and $10.65 \%$ (13) were accidents while in transit.

\section{DISCUSSION}

The presence of young adults in the prime of their productive capacity and the predominance of women in stable relationships as the profile of CHAs are similar to data found in other studies. However, the working time as a CHA of less than three years demonstrates a high turnover, which can be a factor that hinders the development of bonds with families and the community, interfering with work ${ }^{(8-9)}$.

There must be a careful look at the exposure of CHAs to the several workloads that can lead to illness in order to propose strategies to minimize or face these diseases. The exposure to workloads generates strain processes in workers, in the form of accidents or diseases, while processes of destructive adaptation of the body integrity, and implying loss of their effective capacity and/or biopsychic potential. Thus, these strain processes not always lead to the development of diseases or accidents, since it is possible to develop potentials and recover the losses and capabilities ${ }^{(7)}$.

In this study, the workloads were identified from the strain processes suffered by CHAs that resulted mainly from exposure to mechanical, biological, physiological and psychological loads. The number of workloads found (140) was higher than the number of health problems (122), showing the interaction of more than a workload in the strain process workers, which is similar to the result of a study conducted with nursing workers at a university hospital ${ }^{(10)}$.

Some interventions can prevent or minimize some straining aspects resulting from workloads. Due to the many straining aspects resultant from mechanical loads, the CHAs must be fully vaccinated against tetanus. In the case of CHAs who use a bicycle to perform their work activities, it is necessary to wear a bicycle helmet and carry out a routine maintenance of the bicycles. The use of closed shoes according to the Regulatory Norm 32 (NR32) and the use of long pants of full-bodied fabric can also help to decrease injuries in the lower limbs resulting from these mechanical loads.

The high frequency of traffic accidents involving bicycles results from this being the most used means of transport by the study subjects, either to develop their activities in the microarea or to travel to their residences. Just over half of these accidents occurred without collisions, when the bicycle skidded, stopped suddenly due to some object tangled in the wheel or lack of maintenance (brake, loose bicycle handlebars). The collision with a motor vehicle (car, motorcycle and heavy transport vehicle) occurred in one fifth of bicycle accidents; to a lesser extent, there were collisions with another bicycle, pedestrian or animal.

In Canada, a study ${ }^{(11)}$ analyzed 683 accidents involving cyclists attended at the emergency department. It found that about a third of these accidents were collisions with motor vehicles, a third were collisions with resources of infrastructure (post, curb) and surface, and a small number of collisions with cyclists, pedestrians and animals. The rest of the accidents occurred due to falls, many of which resultant from collision avoidance maneuvers. However, the importance of using the helmet and the separation of cyclists from motor vehicle traffic on the main roads is noteworthy, since accidents involving motor vehicles are more serious ${ }^{(11-12)}$.

The dog bites or attacks $(13 ; 10.66 \%)$ occurred on public streets and in the backyards of clients' homes, often in the presence of the pet owners themselves. The falls occurred from the own height, from slipping or tripping (9; 7.38\%), from the stair steps of a building in a dark environment $(2 ; 1.64 \%)$ during home visits and from one level to another (1; $0.82 \%)$ when the CHA fell into an inactive septic tank in the backyard of the patient's residence.

Another study ${ }^{(13)}$ conducted in Canada with health workers found that the risk of falls was significantly higher for support service workers and CHAs. The main factors leading to falls were the type of floor (slippery, uneven surfaces) and outdoor environments. In the United Arab Emirates, falls accounted for $63 \%$ of cases of occupational traumatic brain injury in patients of a hospital, showing the importance of implementing preventive measures ${ }^{(14)}$.

In relation to exposure to inanimate mechanical forces, there was an $(1.25 \%)$ accident with the penetration of a foreign body or object through the skin when a thorn pierced the foot of a CHA who was wearing sandals while conducting home visits. There was contact with a hypodermic needle $(1 ; 1.25 \%)$ when a CHA was signing the record sheet on the same table where a nursing assistant was performing a blood glucose test. The contaminated needle fell and the CHA injured herself when collecting it from the floor (pierced her finger).

The exposure to other inanimate mechanical forces (3; $2.46 \%)$ include cut with a tin and broken toilet during dengue preventive inspection in the residence backyard and with a bicycle rim that broke when the CHA was calibrating the tire, injuring her arm. The open wound of toe(s) with damage to nail $(1 ; 0.82 \%)$ was caused by a CHA who wore wooden clogs and accidentally stepped on the foot of another CHA that was wearing sandals, instantly removing the nail of the second left toe.

Some types of mechanical loads were enhanced by biological loads, such as dog bites, falls in inactive septic tanks, finger perforation with contaminated hypodermic needle, and cuts with tin and broken toilet. In these cases, it is necessary to evaluate and adopt prophylactic measures given the possibility of disease transmission. The dog bites expose workers to the possibility of transmission of rabies and other diseases arising from micro-organisms found in the animals' saliva that require preventive measures against human rabies and tetanus, and antimicrobial treatment according to individual evaluation of cases. In the accident with contaminated hypodermic needle, the serological monitoring for HIV, Hepatitis B and C is of utmost importance, as well as conducting chemoprophylaxis according to the evaluation. In addition, while conducting dengue preventive inspection, it is necessary to use suitable gloves for handling debris. 
For the prevention of respiratory infections resulting from biological loads, the annual influenza vaccination should be offered to CHAs and all the health services employees. This is a World Health Organization guidance that includes health professionals in the most vulnerable group for the control of influenza, because their immunization preserves the workforce and prevents the disease spread in high-risk populations ${ }^{(15)}$. The use of masks and performing the tuberculin test in CHAs who monitor tuberculosis patients are also recommended, since they have a greater risk of tuberculosis infection ${ }^{(16)}$.

As for physiological loads, we suggested the implementation of a labor gymnastics program, guidance on proper posture, respect for lunch and snack breaks, encouraging fluid intake, and changing the type of work done during the day (reports, visits, groups, and other activities).

The intense pace of work, considered a physiological load, contributes to poor diet (fast, high in fat and low in fiber) and poor fluid intake, risk factors for cholelithiasis, and kidney stones and cystitis, respectively. The CHAs reported difficulties in enjoying their lunch breaks in full due to interruptions of patients during their way home and in their own homes.

The most cited diseases of the musculoskeletal system and connective tissue were synovitis and tenosynovitis (5; 4.10\%), which are characterized by wrist numbness and burning. Tendinitis was related to the fact that CHAs write a lot (home visits report, filling out the information system records of primary care) and have to constantly stop their bicycles during transportation between a residence and another. Internal disorders of the knee (3; $2.46 \%$ ) were also mentioned, and are characterized by pain and clicks associated with the constant locomotion by bicycle or on foot.

In a study conducted in Jequié (state of Bahia), Brazil ${ }^{(17)}$, $84.8 \%$ of 316 CHAs had musculoskeletal pain in the seven days prior to the survey, with lower limbs, spine and upper limbs as the most affected.

The psychic loads present in the work of CHAs show the importance of preparing these professionals to deal with situations like the bonds with people in precarious living conditions $^{(18)}$, unemployed, with lack of resources for food, use and abuse of illicit drugs, domestic violence, parental neglect of children, excessive involvement with the community, resistance and lack of understanding from users, serious problems of health or family relationships, death of users $^{(19)}$, low recognition of their work, excessive intensity and pace of work, overvaluation of bureaucracy, and violence as an insecurity factor ${ }^{(20)}$.

Among the circulatory system diseases in this study, the most frequently mentioned were the hypertensive diseases (5; 4.10\%). According to the CHAs, these diseases are related to the concern and tension in the conduction of daily work, and to age. Stress was the most frequent complaint (4; 3.28\%) among the mental and behavioral disorders and according to the CHAs, it is present when they visit some families who demand some actions that are out of their governance (such as scheduling appointments and exams with specialists), and also due to relationship difficulties with the team and some families.

Occupational stress is known as a major factor in the development of hypertension ${ }^{(21)}$. In addition, studies confirm that stress is related to the work process of CHAs. A study ${ }^{(22)}$ conducted in Aracaju (state of Sergipe-SE), Brazil with 236 CHAs found that $61.4 \%$ of them had some manifestation of stress, and more than half were in the resistance phase and presenting physical symptoms. The burnout syndrome, characterized as chronic job stress, has been recently studied in CHAs. In a countryside city of the state of Minas Gerais, Brazil, it was found that all CHAs presented the burnout syndrome; $58.3 \%$ had average level of emotional exhaustion and $54.2 \%$ had high level of depersonalization ${ }^{(23)}$. In the city of Aracaju, $10.8 \%$ of 222 CHAs demonstrate moderate tendency to burnout syndrome and $29.3 \%$ show similar characteristics to the disease ${ }^{(9)}$. A study ${ }^{(24)}$ with professionals of the Family Health Strategy found that even though the burnout syndrome affects workers regardless of their training, gender or position, it was predominant in the group of CHAs compared to other professionals. Internationally, a Chinese study with 1010 workers of Community Health Centers concluded that stress and burnout syndrome are negatively associated with job satisfaction, which in turn, is perceived as a protection to the health of workers ${ }^{(25)}$.

Regarding physical loads, the prolonged and cumulative UV exposure is knowingly harmful to the eyes ${ }^{(26)}$ and skin. While developing their work, the CHAs most frequently expose their faces, necks, arms, legs, hands and eyes to solar radiation, which are regions more prone to skin changes. Moreover, most of this study subjects are young adults, which means they will have more possibilities of solar radiation exposure during their working lives. Thus, it is extremely important that these workers make use of sunscreens, constantly perform self-inspection of the skin, and use UVA and UVB protective shades.

As for skin and subcutaneous tissue diseases, the skin changes were cited due to chronic solar exposure $(3 ; 2.46 \%)$, characterized by face and arms spots. The city where the study was conducted is sunny most of the year, which requires the constant use of sunscreen as Personal Protective Equipment, because the CHAs are exposed to solar radiation daily during the development of their activities.

A study ${ }^{(27)}$ with CHAs and Agents for Combating Endemic Diseases of Minas Gerais/Brazil found that all respondents had at least a skin problem resulting from sun exposure, among which first degree burns, heat stroke, birth spots that changed color, thickness or size, increase in number of spots on the body (freckles), white spots on the face, neck, arms, trunk or legs. A study with 1061 individuals who work outdoors found that personal protective equipment supply and the organizational culture of solar protection are components that contribute for adopting sun protection practices ${ }^{(28)}$.

The chemical load was identified only once in this study, when there was dust on the streets, requiring its paving to minimize this load. 


\section{CONCLUSION}

The work process of CHAs has clearly brought consequences to their health. All the workloads are involved in the strain process, especially the mechanical, biological, physiological and psychological loads. The most common strain processes were due to external causes of morbidity and mortality, and diseases of the musculoskeletal system and connective tissue, resulting from occupational accidents and work-related diseases. The results highlight the impor- tance of promoting preventive and interventional measures in the different realities of the work exercise of CHAs, seeking strategies for minimizing, coping, and preventing diseases, enhancing their health.

The conduction of similar studies in different locations is of utmost importance to enhance the knowledge and support safety measures for these workers, since this study was carried out with CHAs belonging to a single municipality.

\section{RESUMO}

Objetivo: Identificar as cargas de trabalho presentes na atividade laboral dos agentes comunitários de saúde (ACS) e os processos de desgaste decorrentes. Método: Estudo descritivo-exploratório, transversal, quantitativo, realizado com 137 ACS. Os dados foram coletados por meio de questionário e entrevista norteada pelo software de vigilância à saúde SIMOSTE, seguindo os preceitos éticos da legislação vigente. Resultados: Identificou-se 140 cargas de trabalho envolvidas em 122 processos de desgaste representados pelas ocorrências de agravos à saúde do ACS, destacando-se as cargas mecânica (55,00\%) e biológica (16,43\%). Os processos de desgastes mais comuns foram as causas externas de morbidade e mortalidade $(62,31 \%)$ e as doenças do sistema osteomuscular e conjuntivo (10,66\%). Conclusão: Evidenciou-se a partir dos desgastes identificados, que todas as cargas de trabalho estão presentes no processo de trabalho dos ACS, destacando-se a carga mecânica, representada principalmente pelas causas externas de morbidade e mortalidade, as quais se relacionam com os acidentes de trabalho.

\section{DESCRITORES}

Agentes Comunitários de Saúde; Carga de Trabalho; Riscos Ocupacionais; Saúde do Trabalhador.

\section{RESUMEN}

Objetivo: Identificar las cargas de trabajo presentes en la actividad laboral de los agentes comunitarios de Salud (ACS) y los procesos de desgaste consecuentes. Método: Estudio descriptivo exploratorio, transversal, cuantitativo con 137 ACS. Los datos fueron recogidos mediante cuestionario y entrevista orientada por el software de vigilancia sanitaria SIMOSTE, siguiendo los preceptos de la legislación vigente. Resultados: Se identificaron 140 cargas de trabajo involucradas en 122 procesos de desgaste representados por las ocurrencias de agravios a la salud del ACS, destacándose la carga mecánica $(55,00 \%)$ y la biológica $(16,43 \%)$. Los procesos de desgastes más comunes fueron las causas externas de morbilidad y mortalidad $(62,31 \%)$ y las enfermedades del sistema osteomuscular y conjuntivo (10,66\%). Conclusión: Se evidenció desde los desgastes identificados que todas las cargas de trabajo están presentes en el proceso de trabajo de los ACS, destacándose la carga mecánica, representada especialmente por las causas externas de morbilidad y mortalidad, las que se relacionan con los accidentes laborales.

\section{DESCRIPTORES}

Agentes Comunitarios de Salud; Carga de Trabajo; Riesgos Laborales; Salud Ocupacional.

\section{REFERENCES}

1. Brasil. Ministério da Saúde. Portaria n. 2488, de 21 de outubro de 2011. Aprova a Política Nacional de Atenção Básica, estabelecendo a revisão de diretrizes e normas para a organização da Atenção Básica, para a Estratégia Saúde da Família (ESF) e o Programa de Agentes Comunitários de Saúde (PACS) [Internet]. Brasília; 2011 [citado 2014 out. 20]. Disponível em: http://bvsms.saude.gov.br/bvs/saudelegis/ gm/2011/prt2488_21_10_2011.html

2. Brasil. Ministério da Saúde. Portal da Saúde. Histórico da cobertura da Saúde da Família [Internet]. Brasília; 2014 [citado 2014 out. 20]. Disponível em: http://dab.saude.gov.br/portaldab/historico_cobertura_sf.php

3. Baralhas M, Pereira MAO. Prática diária dos agentes comunitários de saúde: dificuldades e limitações da assistência. Rev Bras Enferm. 2013;66(3):358-65.

4. Costa MC, Silva EB, Jahn AX, Resta DG, Colom ICS, Carli R. Processo de trabalho dos agentes comunitários de saúde: possibilidades e limites. Rev Gaúcha Enferm. 2012;33(3):134-40.

5. Laurell AC, Noriega M. Processo de produção e saúde: trabalho e desgaste operário. São Paulo: Hucitec; 1989.

6. Batista PCP, Felli VEA, Mininel VA, Karino ME, Silva SM, Tito RS et al. Using technological innovation as a tool to monitor nursing workers' health. Rev Esc Enferm USP [Internet]. 2011 [cited 2015 Apr 16];45(n.spe):1621-26. Available from: http://www.scielo.br/pdf/reeusp/ v45nspe/en_v45nspea13.pdf

7. Felli VEA, Tronchin DMR. A qualidade de vida no trabalho e a saúde do trabalhador de enfermagem. In: Kurcgant $\mathrm{P}$, coordenadora. Gerenciamento em enfermagem. Rio de Janeiro: Guanabara Koogan; 2011. p. 85-103.

8. Galavote HS, Prado TN, Maciel ELN, Lima RCD. Desvendando os processos de trabalho do agente comunitário de saúde nos cenários revelados na Estratégia Saúde da Família no município de Vitória (ES, Brasil). Ciênc Saúde Coletiva. 2011; 16(1):231-40.

9. Caroline Mascarenhas Mota CM, Dosea GS, Nunes OS. Avaliação da presença da Síndrome de Burnout em Agentes Comunitários de Saúde no município de Aracaju, Sergipe, Brasil. Ciênc Saúde Coletiva. 2014;19(12):4719-26. 
10. Mininel VA, Felli VEA, Silva EJ, Torri Z, Abreu AP, Branco MTA. Workloads, strain processes and sickness absenteeism in nursing. Rev Latino Am Enfermagem [Internet]. 2013 [cited 2015 June 28];21(6):1290-7. Available from: http://www.scielo.br/pdf/rlae/v21n6/01041169-rlae-21-06-01290.pdf

11. Teschke K, Frendo T, Shen H, Harris MA, Reynolds CC, Cripton PA, et al. Bicycling crash circumstances vary by route type: a cross-sectional analysis. BMC Public Health [Internet]. 2014 cited 2015 June 28];14:1205. Available from: http://www.ncbi.nlm.nih.gov/pmc/articles/ PMC4253622/

12. Webman R, Dultz LA, Simon RJ, Todd SR, Slaughter D, Jacko S, et al. Helmet use is associated with safer bicycling behaviors and reduced hospital resource use following injury. J Trauma Acute Care Surg. 2013;75(5):877-81.

13. Drebit S, Shajari S, Alamgir H, Yu S, Keen D. Occupational and environmental risk factors for falls among workers in the healthcare sector. Ergonomics. 2010;53 (4):525-36.

14. Salem AM, Jaumally BA, Bayanzay K, Khoury K, Torkaman A. Traumatic brain injuries from work accidents: a retrospective study. Occup Med (Lond). 2013;63(5):358-60.

15. World Health Organization. Vaccines against influenza WHO position paper - Novembro 2012. Wkly Epidemiol Rec [Internet]. 2012 [cited 2015 June 03];87(47):461-76. Available from: http://www.who.int/wer/2012/wer8747.pdf

16. Zandonade E, Maciel ELN. Risco de infecção tuberculosa em agentes comunitários de saúde. Rev Saúde Pública. 2010;44(2):332-8.

17. Meira-Mascarenhas $\mathrm{CH}$, Ornellas-Prado F, Henrique-Fernandes M. Dor musculoesquelética e qualidade de vida em agentes comunitários de saúde. Rev Salud Publica (Bogotá). 2012;14(4):668-80.

18. Cezar-Vaz MR, Soares JFS, Figueiredo PP, Azambuja EP, Sant'Anna CF, Costa VZ. Risk perception in family health work: study with workers in Southern Brazil. Rev Latino Am Enfermagem [Internet]. 2009 [cited 2014 Dec 26];17(6):961-7. Available from: http://www.scielo.br/ pdf/rlae/v17n6/06.pdf

19. Wai MFP, Carvalho AMP. O trabalho do Agente Comunitário de Saúde: fatores de sobrecarga e estratégias de enfrentamento. Rev Enferm UERJ. 2009;17(4):563-8.

20. Santos LFB, David HMSL. Percepções do estresse no trabalho pelos agentes comunitários de saúde. Rev Enferm UERJ. 2011;19(1):52-7.

21. Matić M, Jovanović J, Jovanović J, Macivanin N. Effects of occupational stress on working ability of patients suffering from arterial hypertension. Med Pregl. 2013;66(11-12):497-501.

22. Santos IER, Vargas MM, Reis FP. Estressores laborais em agentes comunitários de saúde. Rev Psicol Organ Trab. 2014;14(3):324-35.

23. Barroso SM, Guerra ARP. Burnout e qualidade de vida de agentes comunitários de saúde de Caetanópolis (MG). Cad Saúde Coletiva. 2013;21(3):338-45.

24. Trindade LL, Lautert L. Syndrome of Burnout among the workers of the Strategy of Health of the Family. Rev Esc Enferm USP [Internet]. 2010 [cited 2015 Mar 31]; 44(2):274-9. Available from: http://www.scielo.br/pdf/reeusp/v44n2/en_05.pdf

25. Ge C, Fu J, Chang Y, Wang L. Factors associated with job satisfaction among Chinese community health workers: a cross-sectional study. BMC Public Health [Internet]. 2011 [cited 2015 Mar 31];11:884. Available from: http://www.ncbi.nlm.nih.gov/pmc/articles/PMC3248884/

26. Chorley AC, Evans BJ, Benwell MJ. Civilian pilot exposure to ultraviolet and blue light and pilot use of sunglasses. Aviat Space Environ Med. 2011;82(9):895-900.

27. Lima AG, Silva AMM, Soares CEC, Souza RAX, Souza MCMR. Fotoexposição solar e fotoproteção de agentes de saúde em município de Minas Gerais. Rev Eletr Enf [Internet]. 2010 [citado 2015 mar. 31];12(3):478-82. Disponível em: https://www.fen.ufg.br/fen_revista/v12/ n3/v12n3a09.htm

28. Reeder AI, Gray A, McCool JP. Occupational sun protection: workplace culture, equipment provision and outdoor workers' characteristics. J Occup Health. 2013;55(2):84-97. 